\title{
Prevalence of Dental Midline Shifting in a Sample of Orthodontic Patients in Erbil City
}

\section{Deman Hasan Hamid}

Department of Pedodontic, Orthodontic and Preventive Dentistry, College of Dentistry, Hawler Medical University,Erbil, Kurdistan region, Iraq.

Email: deman.hasan@hmu.edu.krd

\section{Asma Qasim Rahman}

Department of Oral maxillofacial surgery, College of Dentistry, Hawler Medical University,Erbil, Kurdistan region, Iraq.

Email: Asma.qasm@hmu.edu.krd

\section{Tara Saleem Hamad}

Department of Pedodontic, Orthodontic and Preventive Dentistry, College of Dentistry, Hawler Medical University, Erbil, Kurdistan region, Iraq.

Email: tara.saleem@hmu.edu.krd

\section{Rebin Ali Mohammed Amin}

Department of Pedodontic, Orthodontic and Preventive Dentistry, College of Dentistry, Hawler Medical University, Erbil, Kurdistan region,Iraq.

Email: rebin.amin@hmu.edu.krd

\begin{abstract}
:
Aim of the study: the study aimed to determine the prevalence of dental midline shifting in a group of orthodontic patients in Erbil City.

Methodology: The study was conducted on 506 orthodontic patients (183 boys and 323 girls), between 13-40 years old, at the orthodontic department, college of dentistry, Hawler Medical University. The data collected from orthodontic records were analyzed according to the gender, type of dentition and Angle Classes of malocclusion. Dental Midline shifting was observed on the patient with respect to the patient's facial midline. SPSS version 20.0 for Windows was used for data analyses using Chi-square Pearson tests and Fischer exact tests. The level of significance was set at $\mathrm{p}<0.05$.
\end{abstract}


Results: Around half of the total orthodontic patients had dental midline shifting $(49.41 \%)$ which was greater in the maxilla (25.89\%) than the mandible (23.52\%). The prevalence of dental midline shifting was more in girls (30.2\%), with permanent dentition (48.02\%) and with Class I (26.28\%) and Class II (18.18) malocclusion.

Conclusions: The prevalence of maxillary-mandibular dental midline shift was seen in around half of the orthodontic patients. Class I patients were found to have a maximum dental midline shift.

Key Words: prevalence, dental midline shift, malocclusion, mixed dentition, permanent dentition.

\section{Introduction:}

The need to improve facial aesthetics is one of the main reasons why patients are addressing the orthodontist. facial symmetry having determining importance in facial aesthetics. Face symmetry and midline coordination are essential criteria for achieving harmony and facial balance (Bidra et al.2009, p176). Ferro et al. 2017 (p e30) define the dental midline as "the reference to a vertical line drawn through the tip of the incisal embrasure between the two maxillary central incisors and parallel to the vertical lines of the esthetic frame of the face". Aesthetic criteria require that certain facial landmarks of the face (the bisector of the pupil, nasion, tip of the nose, tip of the philtrum and chin) be placed in the same axis, forming facial midline (Peng and Cocke, 1999, p.176). For face symmetry, the facial midline must be coincident with the maxillary and mandibular dental midline (Eskelsen et al. 2009; Farhan et al. 2014, p.176).

There are six important midlines that must be determined- facial midline, skeletal midline, maxillary apical base midline, mandibular apical base midline, maxillary dental midline, and mandibular dental midline. These upper and lower midline conditions may occur in different combinations in any patient. All combinations may occur with or without a functional shift of mandible. (Jain et al, 2015, p.287).

Dental midline position relative to the facial midline is an important diagnostic feature in orthodontic treatment planning. Evaluation of dental midline position may be complicated because sometimes other midline facial structures are not well aligned. Correction of the dental midline deviation through orthodontic treatment often requires complex biomechanics, difficult to achieve in the final stages of treatment, especially for an inexperienced orthodontist. (Anistoroaei, et al. 2018, p.177). Accurate early diagnosis will enable the clinician to formulate a proper treatment plan otherwise it may be gotten worse during treatment. (Jain et al 2015, p.288). 
The aim of our study was to establish the prevalence of maxillary and mandibular dental midline shift in mixed and permanent dentition in a group of orthodontic patients from the orthodontic department of the college of dentistry, Hawler Medical University in Erbil City.

\section{Methodology:}

This cross-sectional study was conducted from January to May 2019 at the Department of Orthodontics, College of Dentistry, Hawler medical University in Erbil. Subjects of either gender aged 13-40 years, all anterior teeth present with normal alignment and without any caries, periodontal disease or mobility were included. Individuals excluded from the study were those with history of previous orthodontic treatment, prosthetic treatment in the anterior teeth, trauma, surgery, missing or crowded dentition, major local/systemic problems that affect the growth and development of facial structures or body example, cleft lip and palate.

The sampling frame comprised of 506 orthodontic patients were selected randomly. Informed consent was obtained from all participants after explaining the nature of the study in detail.

Each patient was examined for midline evaluation. During the examination, the patient was instructed to look forward with back straight in sitting posture without using the headrest. The midline evaluation form of each patient was filled by a single investigator included in the study. All midlines were checked by taking philtrum as a guide. The evaluation includes upper dental midline and lower dental midline concerning facial midline. The shifting of the maxillary and mandibular dental midlines was observed. Each recording was checked twice by the same investigator to eliminate the intra-observer error.

All analyses were carried out using SPSS 20.0 for Windows. The statistical evaluation of obtained data was done by descriptive statistics, Chi-square Pearson Tests, Fischer exact tests; any values less than $\mathrm{p}<0.05$ were interpreted as statistically significant. 


\section{Results:}

In the studied group, the dental midline deviation was observed in $23.52 \%(\mathrm{n}=119)$ patients in the mandible and $25.89 \%$ $(\mathrm{n}=131)$ patients in the maxillary arch, resulting in $49.41 \%(\mathrm{n}=250)$ of the patients having the dental midline deviation (Fig. 1). In girls, the deviation of dental midline was more frequent $(30.2 \%, \mathrm{n}=153)$ than in boys $(19.16 \%, \mathrm{n}=97$ boys) (Fig. 2, Table 1).

Series 1

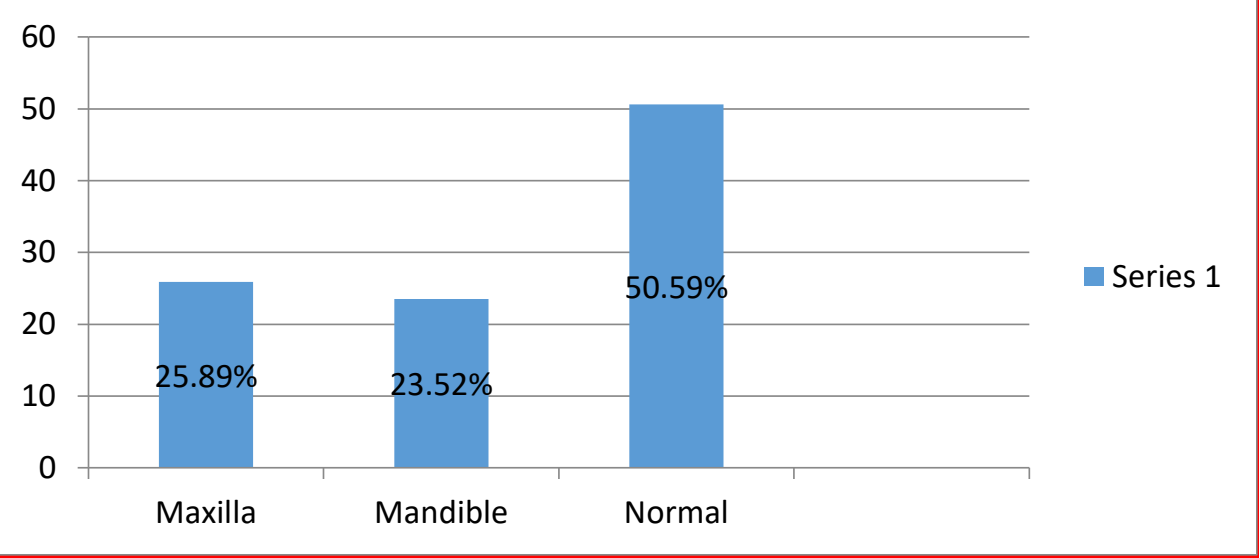

Figure 1. The prevalence of dental midline shifting

In the study group, 7 patients (1.38\%) with mixed dentition and 243 patients (48.02\%) with permanent dentition showed dental midline deviation as shown in (Figure 3, Table 1).

The dental midline deviation was observed in $26.28 \%(\mathrm{n}=133)$ of patients with Angle Class I malocclusion, 18.18\% ( $\mathrm{n}=92)$ of patients with Angle Class II malocclusion and 4.94\% ( $\mathrm{n}=25)$ of patients with Angle class III malocclusion as shown in (Figure 4, Table 1).

statistically nonsignificant correlations were found between the deviation of the dental midline and gender, type of dentition (mixed or permanent) and angle classification as shown in (Table 1). 


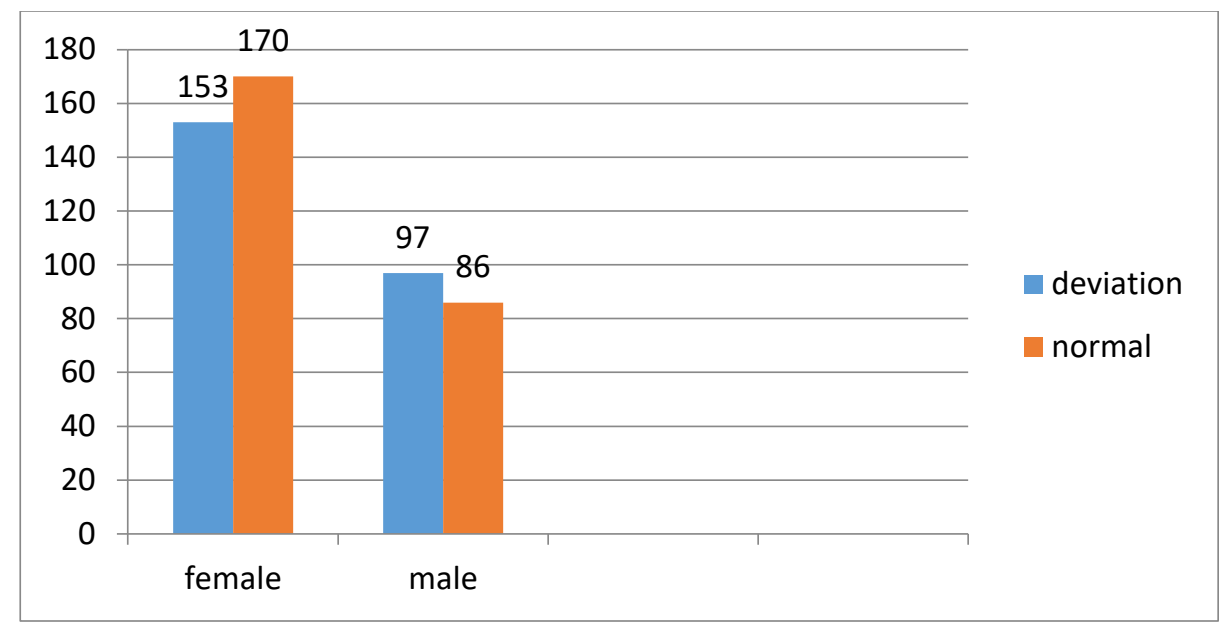

Figure 2. Prevalence of dental midline shifting according to gender.

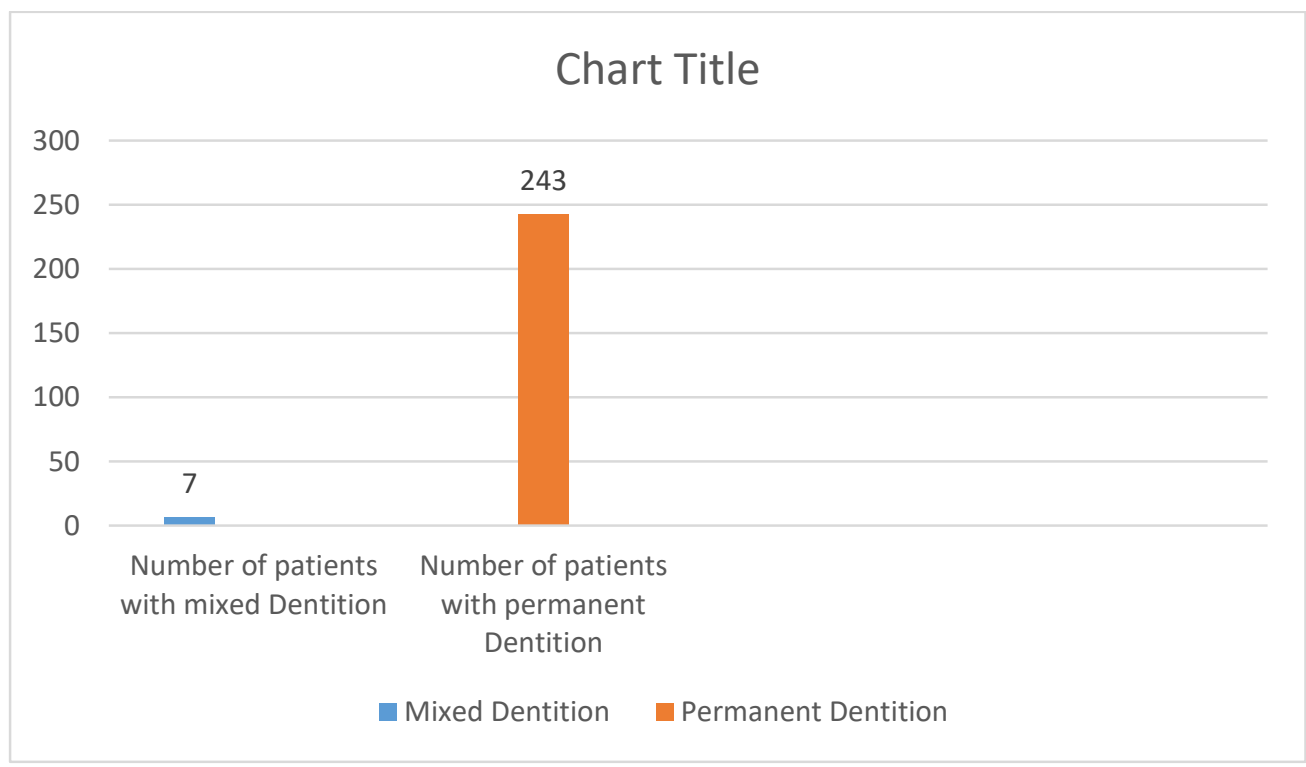

Figure 3. Prevalence of dental midline shifting according to dentition types. 


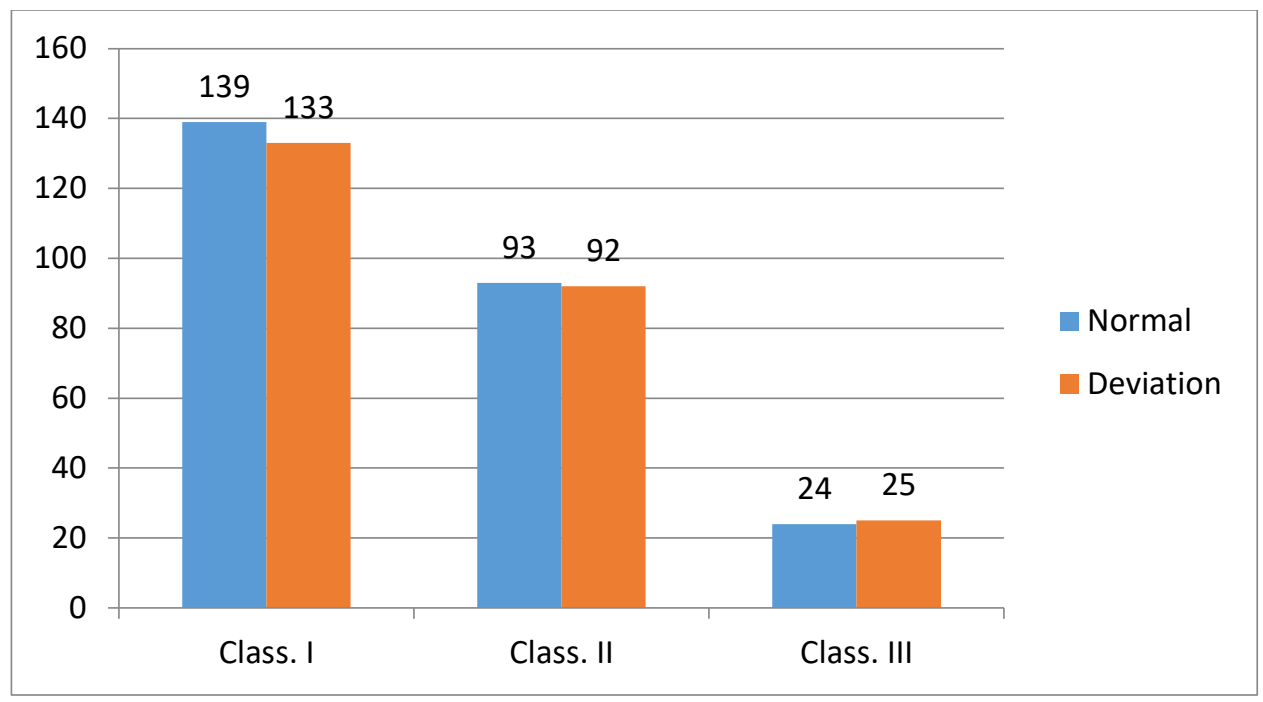

Figure 4. Prevalence of dental midline shifting according to Angle classes of malocclusion

Table 1. The correlations between dental midline shifting of patients and statistical variables

\begin{tabular}{|c|c|c|c|c|c|c|c|c|}
\hline \multirow[t]{2}{*}{ Variables } & \multicolumn{2}{|c|}{$\begin{array}{l}\text { Dental Midline } \\
\text { deviation }\end{array}$} & \multicolumn{2}{|c|}{ Normal } & \multicolumn{2}{|c|}{ Total } & \multirow[t]{2}{*}{$\begin{array}{l}\text { Pearson Chi- } \\
\text { Square test }\end{array}$} & \multirow[t]{2}{*}{$\begin{array}{l}\mathrm{P} \\
\text { value }\end{array}$} \\
\hline & No. & $\%$ & No. & $\%$ & No. & $\%$ & & \\
\hline Gender & 250 & \begin{tabular}{|l|l|}
49.4 \\
\end{tabular} & 256 & 50.6 & 506 & 100 & \multirow[t]{3}{*}{1.48} & \multirow[t]{3}{*}{0.22} \\
\hline Male & 97 & 19.16 & 86 & 17 & 183 & 36.16 & & \\
\hline Female & 153 & 30.24 & 170 & 33.6 & 323 & 63.84 & & \\
\hline $\begin{array}{l}\text { Dentition } \\
\text { types }\end{array}$ & 250 & 49.4 & 256 & 50.6 & 506 & 100 & \multirow[t]{3}{*}{0.044} & \multirow[t]{3}{*}{0.82} \\
\hline Mixed & 7 & 1.38 & 8 & 1.58 & 15 & 2.96 & & \\
\hline Permanent & 243 & 48.02 & 248 & 49.02 & 491 & 97.04 & & \\
\hline $\begin{array}{l}\text { Angle } \\
\text { malocclusions }\end{array}$ & 256 & \begin{tabular}{|l|}
49.4 \\
\end{tabular} & 256 & 50.6 & 506 & 100 & \multirow[t]{4}{*}{0.087} & \multirow[t]{4}{*}{0.95} \\
\hline Class I & 133 & 26.28 & 139 & 27.48 & 272 & 53.76 & & \\
\hline Class II & 92 & \begin{tabular}{|l|}
18.18 \\
\end{tabular} & 93 & 18.38 & 185 & 36.56 & & \\
\hline Class III & 25 & 4.94 & 24 & 4.74 & 49 & 9.68 & & \\
\hline
\end{tabular}

*statistically significant differences when $\mathrm{p}<0.05$. 


\section{Discussion:}

In the current study, the prevalence of dental midline shifting in a group of orthodontic patients according to gender, types of dentition and Angle classes of malocclusions were assessed. Around half of the total patients (49.41\%) had dental midline shifting, which was greater in the maxilla than the mandible slightly. Jayalakshmi et al. 2013, (p.212) observed maxilla-mandibular dental midline discrepancy in almost 80\% of the Indian students. Bhateja et al. 2014, (p.289) also reported that $32.6 \%$ of their sample did not have coinciding dental midlines. A study done by (Anistoroaei et al. 2018, p, 177), reported that midline deviation was $20.70 \%$ with greater in the maxilla $(12.50 \%)$ than the mandible $(8.30 \%)$.

In a study done by (Jain et al. 2015, p, 288), it was found that $77 \%$ of patients showed midline deviation in routine clinical examination. Of the total midline shift, $21 \%$ of patients showed upper dental midline shift and $43 \%$ of patients showed lower dental midline shift which is nearly twice of upper dental midline shift. Similarly, (Khan and Kazim. 2019, p, 212) Khan et al who reported that $(52.1 \%)$ and $(53.88 \%)$ of patients showed a deviation of the maxilla- mandibular dental midline deviation to facial midline, respectively.

The current study agrees with the results of the mentioned studies that demonstrate in patients presenting for orthodontic treatment, the maxillary and/or mandibular dental midlines often do not coincide with each other or with the facial softtissue midline. (Bishara et al. 1994; Nanda and Margolis, 1996, p.180). Bishara and Nanda revealed that this may be due to skeletal asymmetries in which the maxilla or mandible is in malposition relative to the facial skeleton, or due to dental asymmetries resulting from displacement or distortion of the upper or lower dental arches, congenital missing tooth, early loss of deciduous teeth and habits such as thumb sucking.

People consider dental midline discrepancies a factor in reducing smile attractiveness; discrepancies of $2 \mathrm{~mm}$ or more have 56\% chance of being noticed by laypeople (non-professionals) (Johnston et al. 1999, p.212) but also It is considered that minor discrepancy in the midlines is acceptable. (Bhateja et al. 2014, p.212).

The likely match of the facial and dental midline is the initial step in the esthetic rehabilitation of dental patients. (Nold et al. 2014; Ali et al. 2013, p.212). Matching of the maxillary dental midline with the facial midline is more important for the better esthetic outcomes compared with the coincidence of mandibular dental midline with the facial midline. This may be explained by the fact that the maxillary anterior teeth are mainly visible during smile and function. (Bidra et al. 2009, p.212). 
In the current study, the deviation of the dental midline was more frequent in females. This finding agrees with the study done by (Anistoroaei et al. 2018, p.180), that reported midline deviation was greater in girls.

Dental midline shifting was more frequent in patients with Angle class I and class II than those with Angle class III malocclusion. Also, a study done by (Anistoroaei et al. 2018, p.180) showed that the prevalence of midline shifting is seen mostly in patients with Class I (11.20\%) and Class II division 1 (6.25\%) malocclusions. Orthodontic patients with class I Angle malocclusion were found to have a maximum midline shift as reported by (Jain et al. 2015, p.290). This is in agreement with the present study.

The current study show dental midline shifting was more frequent in patients with permanent dentition than those with mixed dentition, however, the deviation of the dental midline which was more frequent in patients with mixed dentition as reported by (Anistoroaei et al. 2018, p, 180) this is in contrast to current study and this is related to the reason that after age of 12 years, dental anomalies of the number, shape, dental size, position, dental crowding, spacing and the consequences of premature loss of temporary teeth causing the establishment of deviation of the maxillary and mandibular dental midlines.

\section{Conclusions:}

1. Dental midline deviation was more common in patients with Angle Class I malocclusions.

2. The dental midline deviation, commonly encountered in orthodontic practice, must be accurately diagnosed from the beginning of the treatment because the symmetry of the midlines is an essential criterion in achieving the aesthetic and functional objectives of the orthodontic treatment.

3. Midline asymmetries require special attention in orthodontic diagnosis and treatment planning because orthodontists often treat patients with dental or facial midline shifts. Coincident midlines are an important component of functional occlusion and can be used as a clinical guide to establish ideal intercuspation. 


\section{References:}

Ali Z, Ashley M, West C. (2013). Factors to consider when treatment planning for patients seeking comprehensive aesthetic dental treatment. Dent Update. 40,526-8.

Anistoroaei D, Zegan G, Saveanu IC, Sodor A, Golovcencu L. (2018). The prevalence of dental midline deviation in a group of orthodontic patients. Romanian Journal of Oral Rehabilitation.10(3), 176-82.

Bhateja NK, Fida M, Shaikh A. (2014). Frequency of dentofacial asymmetries: A crosssectional study on orthodontic patients. J Ayub Med Coll Abbottabad. 26,129-33.

Bidra AS, Uribe F, Taylor TD, Agar JR, Rungruanganunt P, Neace WP. (2009). The relationship of facial anatomic landmarks with midlines of the face and mouth. J Prosth Dent. 102(2),94-103.

Bishara SE, Burkey PS, Kharouf JG. (1994). Dental and facial asymmetries: A review. Angle Orthod. 64,89-97.

Eskelsen E, Fernandes CB, Pelogia F, Cunha LG, Pallos D, Neisser MP, Liporoni PCS. (2009).

Concurrence between the maxillary midline and the bisector to the interpupillary line. J Esthet Restor Dent. 21(1),3742.

Farhan KM, Khezran Q, Sajid N. (2014). Coincidence of facial midline with dental midline. Pak Oral Dental J. 34(2),355-357.

Ferro KJ, Morgano SM, Driscoll CF, Freillich MA, Guckes AD, Knoernschild KL, Mcgarry TJ. (2017)..The Glossary of Prosthodontic Terms. JOURNAL OF proshtodntic . 117 (5s). e1-e105.

Jain S, Jain V, Gupta A. (2015). Prevalence of midline shift in orthodontic patients. International Journal of Current Innovation Research. 1 (10), 287-90.

Jayalakshmi N, Ravindra S, Nagaraj K, Rupesh P, Harshavardhan M. (2013). Acceptable deviation between facial and dental midlines in dentate population. J Indian Prosthodont Soc. 13,473-7. 
Johnston CD, Burden DJ, Stevenson MR. (1999). The influence of dental to facial midline discrepancies on dental attractiveness ratings. Eur J Orthod. 21,517-22.

Nanda R, Margolis MJ. (1996). Treatment strategies tor midline discrepancies. Semin Orthod. 2,84-89.

Nold SL, Horvath SD, Stampf S, Blatz MB. (2014). Analysis of select facial and dental esthetic parameters. Int J Periodontics Restorative Dent. 34,623-9.

Peng L, Cocke MS. (1999). Fifteen-year reproducibility of natural head posture: A Longitudinal study. Am J Orthod Dentofacial Orthop. 116,82-85.

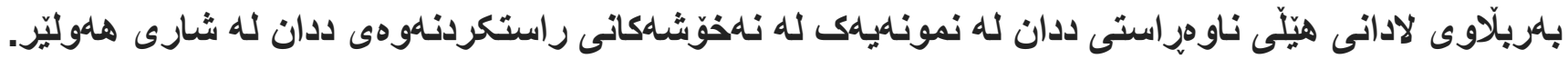

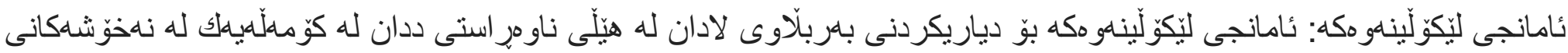
راستكردناوهى ددان.

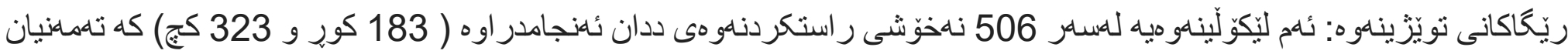
له نيّو ان ( 13 بوّ 40 ) سالّه. ئهو انهى ساهردانى بهشى راستكردنهوهى ددانيان كردووه ، له كوّليزّى يزيشكى ددان. دواتر هلموو

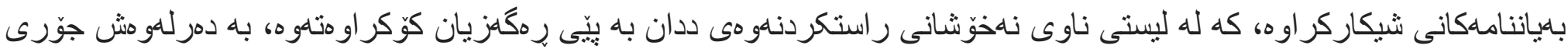

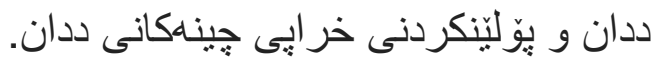

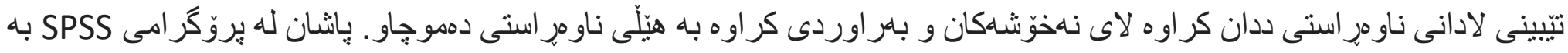

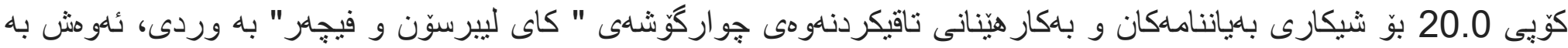
ز زماردنى باشثيّك تاقيكر دناهوهى p0.05.

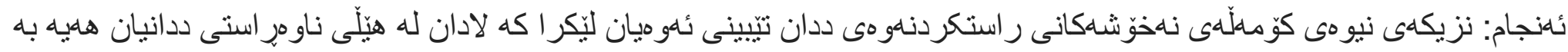

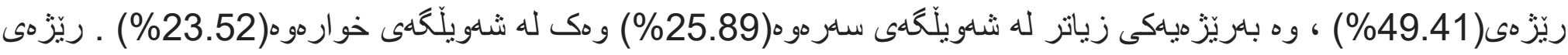




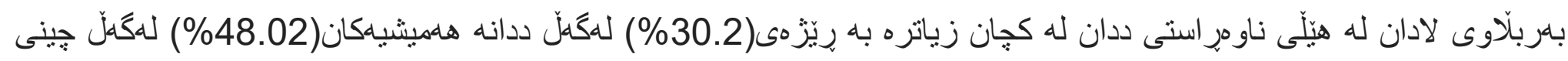

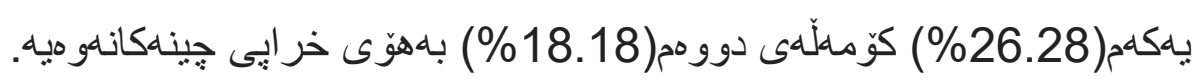

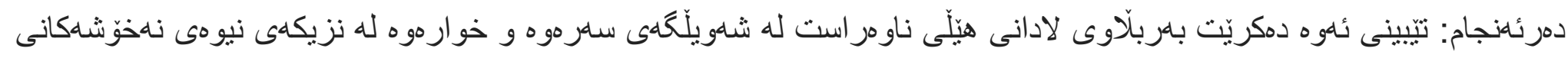

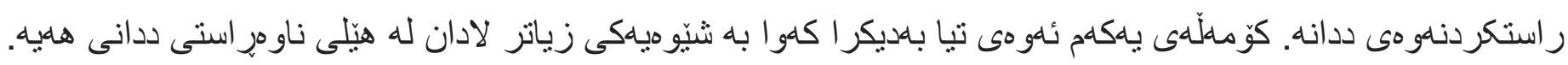

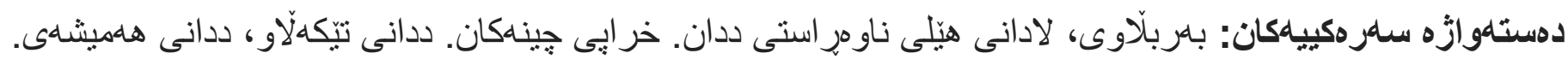

\section{انتشار اتحراف الخط المتوسط السني في عينة من مرضى تقويم الأسنان في مدينة أربيل}

الملخص:

الهدف من الدر اسة: تهدف الدر اسة إلى تحديد مدى انتشار انحر اف الخط المتوسط السني عند مجمو عة من مرضى تقويم الأسنان.

المنهجية: أجريت الدر اسة على 406 من مرضى تقويم الأسنان (183 فتى و 323 فتاة)، نتر اوح ح أعمار هم بين 13 و

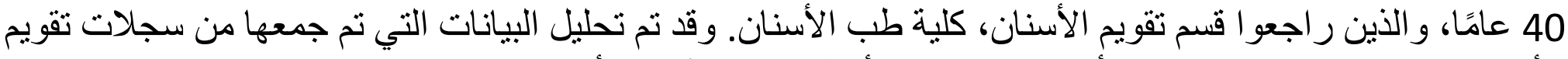

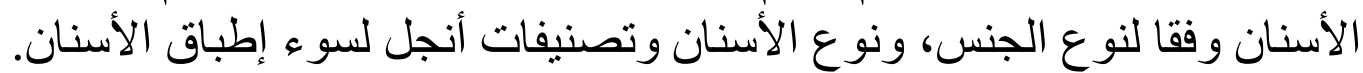

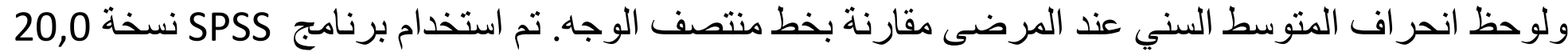

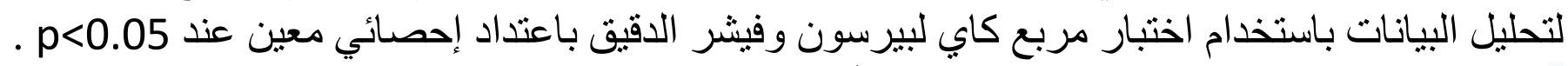

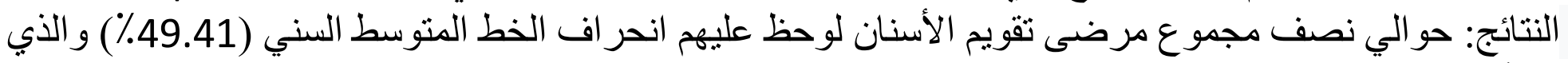

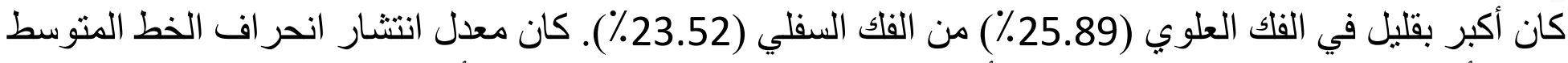

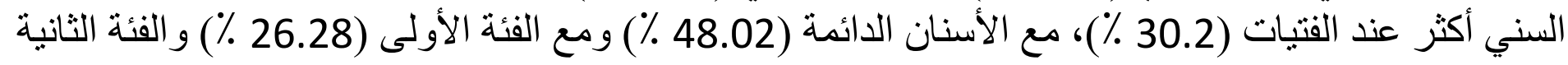
الإن: 18,18)

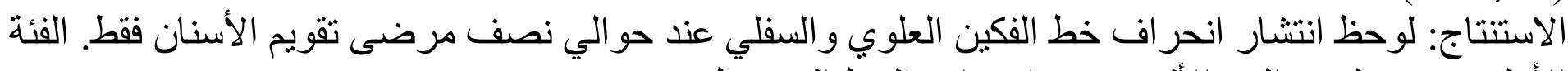

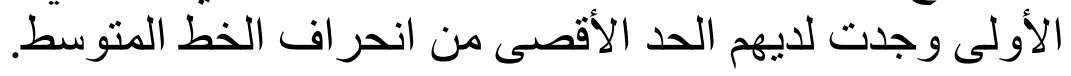

الكلمات الرئيسية :انتشار، انحر اف الخط المتوسط السني، سوء الاطباق، الأسنان المختلطة، الاسنان الدائمة. 